\title{
Evaluation of Online Learning for Inclusive Junior High School Students
}

\author{
Tyas Ratnawati', Rugaiyah², Siti Rochana3 \\ DOI: $10.35445 /$ alishlah.v13i2. 774
}

\section{Article Info}

Keywords:

Education;

Inclusive;

Online Learning

Kata kunci:

Pendidikan;

Inklusif;

Pembelajaran Online

\begin{abstract}
Online learning has been carried out by all levels of education, starting from elementary school to higher education, applied to traditional and inclusive schools. The purpose of the study was to obtain the results of online learning evaluations for inclusive students at State Junior High Schools 36 Jakarta. This study used a descriptive analytical-qualitative approach. Data were collected through observation, interviews, documentation, and group discussion forums. Data analysis techniques consist of data reduction, data presentation, conclusion drawing/verification. The study results concluded that the implementation of online learning was carried out regularly by government standards in terms of planning, implementation, and evaluation. The students also did not experience any problems and were diligent in participating in online learning activities because of parental assistance. The study results also have implications for understanding the concept of cooperation between the school and parents in carrying out online learning activities so that students can take online classes regularly.
\end{abstract}

\begin{abstract}
Abstrak
Pembelajaran online telah dilakukan oleh semua jenjang pendidikan baik mulai dari sekolah dasar sampai pendidikan tinggi yang diberlakukan bagi sekolah regular dan inklusi. Tujuan penelitian adalah untuk mendapatkan hasil evaluasi pembelajaran online bagi siswa inklusi di Sekolah Menengah Pertama Negeri 36 Jakarta. Penelitian ini menggunakan pendekatan kualitatif deskriptif analitis. Data dikumpulkan melalui observasi, wawancara, dokumentasi, dan forum group discussion. Teknik analisis data terdiri dari reduksi data, penyajian data, penarikan kesimpulan/verifikasi. Hasil penelitian menyimpulkan bahwa pelaksanaan pembelajaran online dilakukan secara teratur sesuai dengan standar pemerintah baik perencanaan, pelaksanaan, dan evaluasi. Para siswa juga tidak mengalami kendala dan rajin mengikuti kegiatan pembelajaran daring karena proses pendampingan orang tua yang teliti. Hasil penelitian juga berimplikasi pada pemahaman konsep kerjasama antara pihak sekolah dengan orang tua dalam melaksanakan kegiatan belajar online agar para siswa dapat mengikuti kelas daring dengan teratur.
\end{abstract}

\footnotetext{
${ }^{1}$ Universitas Negeri Jakarta, Indonesia Email: tyassratna@gmail.com

${ }^{2}$ Universitas Negeri Jakarta, Indonesia Email: rugaiyah@unj.ac.id

3 Universitas Negeri Jakarta, Indonesia

Email: sitirochanah@unj.ac.id
} 


\section{INTRODUCTION}

The Covid-19 pandemic has forced changes in human life. In this case, the process of providing education has also undergone considerable changes. Currently, the educational process utilizes information and communication technology in carrying out learning activities. The entry of ICT into education is a valuable opportunity to make some modifications and innovations that result in increased efficiency and more effects of the education system (Bidarian et al., 2011). Various technological applications have been built by utilizing technological advances. Online learning activities can now be used with various multimedia such as zoom, google meet, learning websites, and so on. Various applications of technology as a product of ICT have been used in education.

Various face-to-face teaching and learning activities have been changed to online, not least for students with special needs or implementing inclusive education. Inclusive education is aimed at students who have disabilities and have the potential for intelligence and unique talents to participate in education or learning in an educational environment and students in general. It requires a school environment that can stimulate students to develop their potential and facilitate useful social life in the future, especially for their work. Thus, the condition of the student's personality must be considered following his ability to maximize his potential. Teacher feedback behavior is the primary determinant of the social reference process that affects students' social acceptance (Wullschleger et al., 2020). The Czech Republic or several countries in Europe have formed a curriculum and strategic steps to provide education (Kratochvílová \& Havel, 2014). Children with special needs can interact with normal conditions if the proper treatment is done. It is in line with the government program that children with special needs have the same rights as other children and can live independently, excel in accordance with their interests and potential. For this reason, parents, families, and communities must be responsible for fulfilling children's rights in all aspects of life, such as socializing in the environment, recreation, and other activities aimed at introducing children with special needs to life outside the home.

Therefore, schools and stakeholders must be ready to organize online learning. Against the backdrop of the ongoing Covid-19 pandemic, the availability of supporting facilities and infrastructure and easy internet access among rural communities, financial assistance and socialization of the importance of online learning is very much needed (Febrianto et al., 2020). In inclusive schools, students living in the digital age benefit from digital technology and a digitally enhanced educational environment without isolation and exclusion. It also has an impact on increasing teacher confidence in using digital technology and the instructional competencies and digital skills of students and teachers (Kim et al., 2021)

The learning process for inclusive children has become even more difficult with the extraordinary occurrence of the corona pandemic, where all learning processes are online. It changes the entire mechanism of life and society quickly and unexpectedly, including in Indonesia. President issued Presidential Decree of the Republic of Indonesia Number 12 of 2020 concerning the Designation of Non-Natural Disasters for the Spread of Corona Virus Disease 2019 as National Disasters. Then it gave birth to many policy restrictions in various lines of life in Indonesia. These restrictions impact various factors of people's lives, one of which is in the world of education.

The Minister of Education and Culture issued a Circular Letter of the Minister of Education and Culture Number 4 of 2020 concerning the Implementation of Educational Policies in the Emergency Period for the Spread of Corona Virus Disease (COVID-19) regarding distance learning. The Education Office responded it by issuing Circular Letter No. 33/SE/2020 concerning Distance Learning / Meaningful and Fun Home Learning. The circular explains what things must be considered in the implementation of the Distance Learning Program in the DKI Jakarta school environment. So that the entire learning process in DKI Jakarta is carried out from home via virtual. Virtual learning at school applies to all children, including children with special needs. This is a challenge for schools and children with special needs in conducting the online learning process. 
Especially for students with special needs, the proper learning facilities significantly affect teaching and learning outcomes. Equal opportunity to get education for inclusive children is a mandate of human rights. Furthermore, it is to see inclusive education during the COVID-19 pandemic as an extraordinary situation. Researchers conducted a study to evaluate the implementation of inclusive learning conducted online in the East Jakarta area. This research is essential for the reasons; 1) The number of junior high schools in DKI Jakarta for inclusive education is quite a lot placed in 36 Junior High Schools, 2) The Decree of the Head of the DKI Jakarta Education Office Number 623 of 2012 which states that 36 State Junior High Schools are schools that are required to provide educational services inclusive education in East Jakarta, 3) administrative processes both related to inclusive children, 4) the classification of children with special needs is very varied, namely blind, mute, and slow learners so that it is expected to provide a complex picture of the learning process for inclusive children, and 5) steps from the school and government in organizing online learning for inclusive children, whether it is by the context of their needs.

Therefore, teachers must have the ability to pay attention and reason about classroom situations, including active learning, instructional clarity, adaptive teaching, and flexible grouping (Vantieghem et al., 2020), and teachers in inclusive classes can also build student resilience (Mu et al., 2017). In this case, the school or classroom environment significantly influences the development of e-learning and inclusive education. All parties in schools must collaborate in creating successful learning (Meskhi et al., 2019). The concepts of e-learning and e-teaching play an essential role in educational technology applied in different educational contexts (Bjekić et al., 2014). In this case, digital technology has influenced teaching and learning activities for all levels of education, both regular and inclusive (Keengwe \& Georgina, 2012). Online learning activities must be built through the link between innovative school management processes and an education system that can adapt to pandemic conditions. Various problems in implementing online learning activities can be handled appropriately (Mishra et al., 2020).

From previous research, it has been known that implementing inclusive education requires concepts and contexts that are by the background of students' privileges and social. In this case, the implementation of learning activities must be supported by various learning tools such as technology, materials, strategies, and learning media. Moreover, online learning activities require enormous efforts to achieve learning objectives. Therefore, this study evaluated the concept of online learning for inclusive education for junior high school students. So, this research is useful in improving online learning according to the context of inclusive students. Thus, this research aims to evaluate online learning that has been implemented in junior high schools in Jakarta.

\section{METHODS}

This study describes the results of online learning for inclusive children at State Junior High Schools 36 Jakarta during the COVID 19. So, it is a type of descriptive analytical qualitative research. The descriptive-analytical approach is carried out to examine an object or a condition that aims to make a descriptive/systematic description of the problem being studied. In this case, the research was conducted to understand the phenomenon of what was experienced by the research subject, such as behavior, perception, motivation, action, holistically, and by describing it in the form of words and language, in a particular context that naturally and by utilizing various natural methods (Creswell \& Creswell, 2018).

This study's data collection techniques were carried out using observation, interviews, group discussion forums (FGD), and documentation. Observations are carried out directly to schools to obtain accurate data without being influenced by internal or external factors. In-depth interviews were conducted with informants, namely school principals and Counseling Guidance teachers as coordinators of inclusive children. FGDs were conducted with parents of inclusive children to discuss online learning. The FGD will be conducted in groups of 2-3 parents of inclusive students, using 
health protocols. The documentation collected is documentation related to the research location, letters regarding the implementation of activities, and other documentation related to managing inclusive children's learning during the COVID 19 pandemic. The data analysis used three streams of activities simultaneously: data reduction, data presentation, conclusion drawing/verification (Miles \& Huberman, 1994).

\section{FINDINGS AND DISCUSSION}

The results of the data analysis from interview and observation that have been obtained are described in the following matrix;

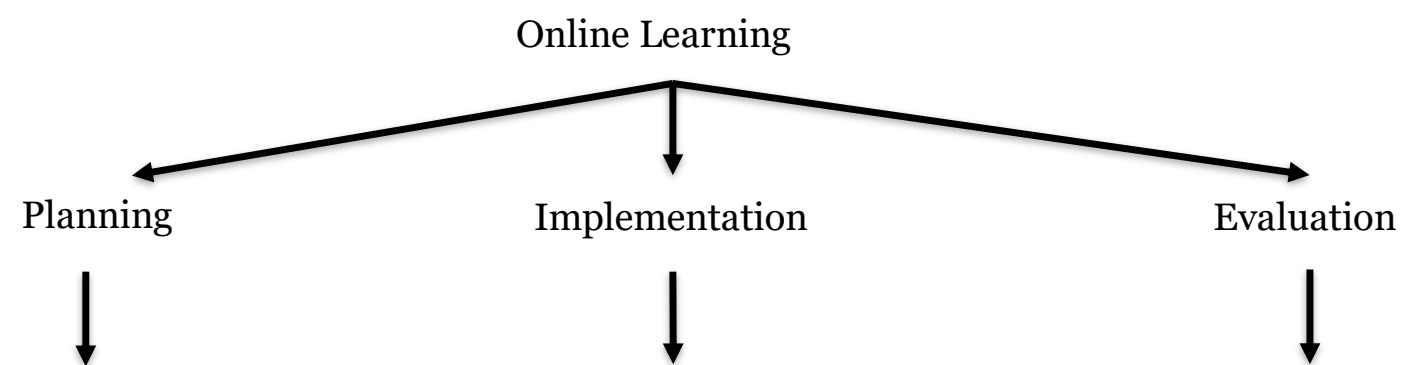

Government standard:

1. Curriculum

2. Syllabus

3. Material

4. Assessment

5. Academic calendar

6. Learning Schedule

7. Annual program in the school related with the learning
1. Learning used gadget and laptop

2. Learning activities are carried out according to the class schedule,

3. Teaching activities are carried out in a class

4. Interactive learning

5. Learning strategies according to online context
1. Evaluation is done by attitude and knowledge

2. Learning outcomes are evaluated according to the planned link

From the data display of the findings above, it can be seen that learning planning is carried out at the beginning of each new school year as a form of school management. At the beginning of the new school year, the principal, vice-principal, classroom teachers and Guidance Counseling teachers as coordinators of inclusive students hold an annual meeting to discuss learning tools. From the results of the interviews, it was also known that the school had a well-planned annual agenda from planning, implementing education and evaluating learning outcomes. When observation activities are carried out at schools, the principal has shown documents related to learning tools. This document is always neatly arranged and revised every semester by the evaluation of learning outcomes. Learning tools are learning planning documents that contain academic calendars, teaching schedules, annual programs, details of the effective week, semester programs, syllabus, lesson plans and minimum graduation criteria. The school has used a regular class model of "full inclusion" where students with disabilities/particular educational needs study together with other students in regular/inclusive classes throughout the day using the same curriculum used by students in general. There is also no difference in the curriculum for inclusive students with regular students during the pandemic's online learning planning process.

The implementation of online learning has utilized the use of technological devices such as gadgets and laptops. Learning activities are also carried out according to the class schedule set by the school. Interactive communication in the online space has been facilitated by various technological applications so that the meaning of learning becomes meaningful. From the results of observations and interviews with school principals and teachers, it was also concluded that the online learning process during the COVID-19 pandemic had utilized facilities built from technology. 
The online learning process is carried out using gadgets or laptops through several portals and learning applications (online media) and offline methods (offline media) (Qazi et al., 2021). For online, in the form of zoom meetings, google meetings, google classroom, WhatsApp groups, youtube channels and online learning resources from the ministry of education. As for offline media with several mechanisms, such as students are required to summarize material from books, reflect on the process and learning outcomes. The teacher gives assignments as evaluations on the google form. The online learning process consists of preliminary, core and closing activities. The teachers have also taken advantage of the google form link used to submit assignments.

Learning evaluation is divided into two categories, namely, the assessment of attitudes and the assessment of knowledge. Attitudes are assessed based on how to communicate in the WA group or google classroom and timeliness in collecting assignments. Knowledge assessment uses a written test with google form media with a pre-planned link. For the types of questions, there is no difference between inclusive students and regular students. It can be seen in the learning implementation plan document in the evaluation technique section, where there is no difference between inclusive and regular students. Inclusion students in the collection of assignments are much more disciplined than regular students. Based on the score recapitulation file, it can be seen that the test scores of inclusive students can be much higher than those of regular students. This is inseparable from the active participation of parents in the learning process.

The Covid-19 pandemic has presented a significant challenge in carrying out online learning activities. It has introduced the idea of a "new normal" in everyday life that influenced life, study and work. During these unprecedented times, the rapid transition from traditional face-to-face learning to online learning has been seen as a paradigm shift in education (Shah et al., 2021; Sutiah et al., 2020; Mishra et al., 2020). Teachers in inclusive classes must adapt and transform lecture learning activities into innovative learning strategies according to the needs of inclusive students (Khanna \& Kareem, 2021). In addition, to manage online classes, teachers must have the attitude, self-efficacy, and background that can handle inclusive children (Yada et al., 2018) so that interactions between teachers and students, students with students, or students with online learning media can be more interactive (Dukuzumuremyi \& Siklander, 2018). Planning, preparation, implementation, and evaluation of online learning activities in New Normal has received significant attention from all parties (Prahani \& Cheng, 2020)

\section{CONCLUSION}

Online learning activities have been carried out very well, starting from planning, implementation, and evaluation. The rules set by the government make the online learning planning process. The provision of curriculum, syllabus, teaching materials, assessments, determination of academic calendars, learning schedules, and annual programs have been prepared by the education implementation regulations from the government and designed according to the meeting agreement. However, the curriculum and syllabus are still adapted to the context of learning needs so that the graduates want to produce an answer to global challenges. In addition, it also presents innovations related to materials, learning strategies, and learning media.

The implementation of online learning is also carried out with various innovations to meet the needs of inclusive children. Innovation in the field comes from teachers who wholeheartedly guide inclusive students. Learning activities that use gadgets make it easier for students to do assignments. Inclusive children are more active in collecting assignments than regular students. The active participation of parents of inclusive students and two-way communication between teachers and parents of inclusive students is one of the keys to the successful implementation of online learning. Thus, various obstacles encountered during online learning activities can be overcome by interactive communication.

While evaluating online learning outcomes includes attitudes and knowledge, evaluation activities are also taken from the links that have been made. This link is a link for students to submit 
assignments. Online-based inclusive learning can be an alternative to post-pandemic companion class system learning because inclusive students can enjoy online learning alternatives to be more exciting and exciting. The basic idea of inclusive education in public schools is to develop independence and socialization.

\section{REFERENCES}

Barnard-Brak, L., Lan, W. Y., \& Paton, V. O. (2010). Profiles in self-regulated learning in the online learning environment. International Review of Research in Open and Distance Learning, 11(1), 61-8o. https://doi.org/10.19173/irrodl.v11i1.769

Bidarian, S., Bidarian, S., \& Davoudi, A. M. (2011). A model for application of ICT in the process of teaching and learning. Procedia - Social and Behavioral Sciences, 29, 1032-1041. https://doi.org/10.1016/j.sbspro.2011.11.336

Bjekić, D., Obradović, S., Vučetić, M., \& Bojović, M. (2014). E-teacher in Inclusive e-education for Students with Specific Learning Disabilities. Procedia - Social and Behavioral Sciences, 128, 128-133. https://doi.org/10.1016/j.sbspro.2014.03.131

Creswell, J. W., \& Creswell, J. D. (2018). Research Design: Qualitative, Quantitative, and Mixed Methods Approaches Fifth Edition. SAGE Publications Inc.

Dukuzumuremyi, S., \& Siklander, P. (2018). Interactions between pupils and their teacher in collaborative and technology-enhanced learning settings in the inclusive classroom. Teaching and Teacher Education, 76, 165-174. https://doi.org/10.1016/J.TATE.2018.08.010

Febrianto, P. T., Mas'udah, S., \& Megasari, L. A. (2020). Implementation of online learning during the covid-19 pandemic on Madura Island, Indonesia. International Journal of Learning, Teaching and Educational Research, 19(8), 233-254. https://doi.org/10.26803/ijlter.19.8.13

Keengwe, J., \& Georgina, D. (2012). The digital course training workshop for online learning and teaching. Education and Information Technologies, 17(4), 365-379. https://doi.org/10.1007/s10639-011-9164-x

Khanna, R., \& Kareem, D. J. (2021). Creating inclusive spaces in virtual classroom sessions during the COVID pandemic: An exploratory study of primary class teachers in India. International Journal of Educational Research Open, 2-2, 100038.

https://doi.org/10.1016/j.ijedro.2021.100038

Kim, H. J., Yi, P., \& Hong, J. I. (2021). Are schools digitally inclusive for all? Profiles of school digital inclusion using PISA 2018. Computers and Education, 170, 104226. https://doi.org/10.1016/j.compedu.2021.104226

Kratochvílová, J., \& Havel, J. (2014). Terms of Inclusive Education in Primary Schools - National and School Curriculum. Procedia - Social and Behavioral Sciences, 141, 337-341. https://doi.org/10.1016/j.sbspro.2014.05.058

Meskhi, B., Ponomareva, S., \& Ugnich, E. (2019). E-learning in higher inclusive education: needs, opportunities and limitations. International Journal of Educational Management, 33(3), 424-437. https://doi.org/10.1108/IJEM-09-2018-0282

Miles, M. B., \& Huberman, A. M. (1994). Qualitative Data Analysis; An Expanded Sourcebook. Sage Publication.

Mishra, L., Gupta, T., \& Shree, A. (2020). Online teaching-learning in higher education during lockdown period of COVID-19 pandemic. International Journal of Educational Research Open, 1, 100012. https://doi.org/10.1016/j.ijedro.2020.100012

Mu, G. M., Hu, Y., \& Wang, Y. (2017). Building resilience of students with disabilities in China: The role of inclusive education teachers. Teaching and Teacher Education, 67, 125-134. https://doi.org/10.1016/j.tate.2017.06.004

Prahani, B. K., \& Cheng, T.-H. (2020). "New Normal" in Learning and Teaching. Studies in Learning and Teaching, 1(2), 63-65. https://doi.org/10.46627/silet.v1i2.41

Qazi, A., Qazi, J., Naseer, K., Zeeshan, M., Qazi, S., Abayomi-Alli, O., Said Ahmad, I., Darwich, M., Ali Talpur, B., Hardaker, G., Naseem, U., Yang, S., \& Haruna, K. (2021). Adaption of distance learning to continue the academic year amid COVID-19 lockdown. Children and Youth Services Review, 126, 106038. https://doi.org/10.1016/j.childyouth.2021.106038

Shah, S. S., Shah, A. A., Memon, F., Kemal, A. A., \& Soomro, A. (2021). Online learning during the COVID-19 pandemic: Applying the self-determination theory in the 'new normal.' Revista de Psicodidáctica (English Ed.). https://doi.org/10.1016/j.psicoe.2020.12.003 
Sutiah, S., Slamet, S., Shafqat, A., \& Supriyono, S. (2020). Implementation of distance learning during the covid-19 pandemic in faculty of education and teacher training. Cypriot Journal of Educational Sciences, 15(5), 1204-1214. https://doi.org/10.18844/cjes.v15i5.5151

Vantieghem, W., Roose, I., Gheyssens, E., Griful-Freixenet, J., Keppens, K., Vanderlinde, R., Struyven, K., \& Van Avermaet, P. (2020). Professional vision of inclusive classrooms: A validation of teachers' reasoning on differentiated instruction and teacher-student interactions. Studies in Educational Evaluation, 67, 100912. https://doi.org/10.1016/j.stueduc.2020.100912

Wullschleger, A., Garrote, A., Schnepel, S., Jaquiéry, L., \& Moser Opitz, E. (2020). Effects of teacher feedback behavior on social acceptance in inclusive elementary classrooms: Exploring social referencing processes in a natural setting. Contemporary Educational Psychology, 6o, 101841. https://doi.org/10.1016/j.cedpsych.2020.101841

Yada, A., Tolvanen, A., \& Savolainen, H. (2018). Teachers' attitudes and self-efficacy on implementing inclusive education in Japan and Finland: A comparative study using multigroup structural equation modelling. Teaching and Teacher Education, 75, 343-355. https://doi.org/10.1016/J.TATE.2018.07.011 